\title{
3.3 Організаційно-економічні механізми управління інфраструктурним розвитком туристичної галузі регіону
}

В умовах посилення європейських та світових інтеграційних процесів туристична галузь набуває особливого стратегічного значення для соціальноекономічного розвитку України та ії регіонів. Вона сприяє становленню країни на світовому ринку товарів та послуг як повноправного партнера міжнародних відносин.

Розвиток туризму істотно впливає на такі інфраструктурні сектори економіки, як транспорт, торгівля, зв'язок, будівництво, сільське господарство, виробництво товарів широкого вжитку, і є одним 3 найбільш перспективних напрямів структурних змін.

У зв'язку з вищезазначеним виникає проблема вивчення та аналізу інфраструктури туристичної галузі, як стрімко зростаючого організаційноекономічного механізму національної та регіональної економік.

На думку Тридід О.М. організаційно-економічний механізм - це сукупність підсистем соціально-економічних i організаційно-економічних відносин, складених з блоків і відповідних їхньому змісту елементів, особливості наповнення яких відповідають розвитку суспільно-економічного устрою» [85].

В свою чергу Транченко Л. В. «під організаційно-економічним механізмом розуміє систему організації й управління, що включає певну сукупність взаємопов'язаних організаційно-правових, економічних та мотиваційних методів, які мають специфічні особливості у конкретних умовах суспільного виробництва» [86].

Малицький А.А. запропонував таке визначення організаційно-економічного механізму - це комплексна система, що складається з системи забезпечення, функціональної та цільової системи, які містять певну сукупність організаційних i економічних важелів, які впливають на економічні і організаційні параметри системи управління підприємством 3 метою забезпечення ефективності управління і отримання конкурентних переваг [87]. 
Потрібно відзначити, що за допомогою організаційно-економічного механізму формується інфраструктурна складова функціонування та розвитку туристичної сфери регіону та країни в цілому.

Інфраструктура туризму служить необхідною умовою освоєння рекреаційних ресурсів та функціонування туристичної індустрії. Її розвиток, 3 одного боку, сприяє туристичному освоєння території, а з іншого - покращує умови життя населення регіону, створюючи велику кількість робочих місць. I хоча поняття туристичної інфраструктури не є новим, у вітчизняній науковій літературі, однак немає його єдиного тлумачення. Неоднозначність і розмитість змістовного сенсу цього поняття пояснюється необгрунтованістю чітких ознак віднесення до інфраструктури туризму окремих видів господарської діяльності та невизначеністю кола їі об'єктів.

Зазначимо, що інфраструктуру туризму можна розглядати як комплекс видів діяльності щодо створення умов для реалізації туристичних послуг. Також існує і розуміння туристичної інфраструктури як сукупності різноманітних об'єктів, що використовуються для задоволення потреб туристів.

Так, наприклад, у Законі України «Про внесення змін і доповнень до Закону України «Про туризм» туристичну інфраструктуру визначають, як сукупність певних суб'єктів туристичної діяльності (індивідуальні та колективні засоби розміщення, заклади харчування, культури, розваг та спорту, медичних та оздоровчих послуг курортної сфери, торгівлі, земельні ділянки, транспортні засоби та транспортні підприємства (перевізники), інформаційні ресурси та інформаційні системи, а також інші матеріальні і нематеріальні блага, майно, майнові комплекси (підприємства), результати та продукти інтелектуальної діяльності), що належать суб'єктам туристичної діяльності. Отже, це різного призначення споруди, транспортні шляхи, засоби комунікації, які використовуються для виробництва та надання комплексних та/або окремих туристичних пакетів та туристичних послуг [88].

На думку Поступної О.В та Леоненко Н.А туристична інфраструктура - це сукупність підприємств, установ і закладів, діяльність яких спрямована на 
задоволення потреб людей, котрі беруть участь в оздоровленні або відпочинку, а також шляхів сполучення і транспорту та об’єктів розміщення туристів, що забезпечують умови стабільного функціонування туристичної галузі [89].

В свою чергу Мельниченко О.А. під інфраструктурою туризму розуміє комплекс споруд, інженерних i комунікаційних мереж, в тому числі телекомунікаційного зв'язку, доріг, суміжних індустрії туризму підприємств, що забезпечують нормальний доступ туристів до туристичних ресурсів і їх належне використання в цілях туризму, забезпечення життєдіяльності підприємств індустрії туризму і власне туристів [90].

Потрібно зазначити, що відповідно до призначення у суспільстві й економіці розрізняють виробничу та соціальну туристичну інфраструктуру. Такий умовний поділ пов'язаний з тим, що низка галузей і виробництв економіки обслуговують як потреби туристичних підприємств (організацій, установ, компаній), так і населення, як споживачів туристичних послуг. У свою чергу виробнича інфраструктура складається 3 транспортної, інформаційнокомунікативної та комунальної інфраструктур, екологічних об'єктів. Соціальна інфраструктура включає в себе такі елементи, як туроператори і турагенти, засоби розміщення, підприємства відпочинку та розваг, торгівля і громадське харчування, інфраструктура безпеки.

В цілому можна погодитися 3 думкою А. Гайдук, який представляє туристичну інфраструктуру у вигляді трьох складових: інституційної (транспорт, готелі, банки, страхові компанії, туристичні фірми, рекламні підприємства тощо), інформаційної (засоби розповсюдження інформації) та регламентуючої (нормативно-правові акти) [91].

Основною метою розвитку туристичної галузі Херсонської області $\epsilon$ створення досконалої інфраструктури та конкурентоспроможного туристичного продукту, поліпшення якості та доступності туристичних послуг, оскільки туризм підтвердив статус однієї 3 найбільш динамічних та перспективних галузей економіки регіону, яка позитивно впливає на динаміку росту соціально економічних показників та стимулювання розвитку суміжних галузей. 
Велика кількість територій та об'єктів туристичної та загальної інфраструктури потребують значних фінансових інвестицій. На заходи для їх залучення, у середньому, витрачається 5,4 \% коштів регіональних програм [92].

Важливою складовою формування будь-якого туристичного продукту є транспортне забезпечення. Тому, доцільно розглянути ситуацію зі станом транспорту та дорожнього господарства в регіоні.

Так, важливим інфраструктурним проектом, який реалізований в області $\epsilon$ міжнародний аеропорт «Херсон», де особлива увага приділяється підвищенню авіаційної безпеки, забезпеченню комфортних умов для пасажирів та залученню до роботи нових авіакомпаній. Кабінет Міністрів України затвердив Державну цільову програму розвитку аеропортів на період до 2023 року, до якої увійшли 17 аеропортів України, серед них і аеропорт «Херсон». Реалізація вказаної державної програми дасть змогу модернізувати до найсучасніших міжнародних стандартів інфраструктуру аеропорту, сприятиме розвитку авіаційних перевезень в області, забезпечить набуття Україною статусу транзитної держави з урахуванням іiі унікального географічного розташування [93].

В регіоні активно впроваджується та реалізується концепція розвитку автобусних перевезень в області, відповідно до якої додатково відкрито понад 30 щоденних сезонних автобусних маршрутів міжміського та міжобласного сполучення (Харків - Стрілкове; Нікополь - Скадовськ; Кам'янське - Скадовськ - Залізний Порт; Херсон - Щасливцеве, Стрілкове, Лазурне, Залізний Порт, Більшовик; Скадовськ - Київ, Генічеськ - Стрілкове. Відновлені регулярні автобусні міжнародні рейси до міст Варшава, Кельн, Прага, Варна, Кишинів та інших міст Європи, що в свою чергу, сприяє поїздкам іноземних громадян до курортних зон на узбережжях Чорного та Азовського морів [94].

Для створення безпеки автотуристів та приведення у належний стан автотранспортних шляхів, проводиться ремонт доріг, що ведуть до курортних населених пунктів Арабатської стрілки Генічеського району, селищ Залізний Порт і Приморське Голопристанського району, міста Скадовська та селища 
міського типу Лазурне Скадовського району, селища Хорли Каланчацького району [95].

Розвиток залізничної інфраструктури дає новий поштовх до розвитку курортів Херсонщини. На літній період щорічно запроваджується 11 потягів через залізничний вокзал станції «Херсон» до столиці та обласних центрів України: Київ, Львів, Харків. Через залізничні станції «Нова Олексіївка» i «Генічеськ» - запроваджено на літній період 19 пар нових потягів, 3 них 9 електричних. Швидкісне сполучення півдня України зі столицею сприяє збільшенню кількості пасажирів, які виявляють бажання відвідати курорти Херсонщини (їх кількість вже на сьогодні перевищує 3,5 млн. осіб) та зробить робочі і ділові візити більш оперативними [96].

Херсонський річковий порт (річковий вокзал) - це великий транспортний вузол, в якому здійснюється взаємодія річкового, морського, залізничного та автомобільного транспорту. Також приймаються річкові пасажирські судна пасажиромісткістю до 700 осіб. Пасажирські перевезення (зазвичай на місцевих лініях) здійснюються з 18 березня по 10 листопада. В цей період в середньому буває до 10 заходів суден на день [97]. Спільно з судноплавною компанією ТОВ СП «НІБУЛОН» проводиться масштабна робота відновлення пасажирських перевезень морським та річковим транспортом, запроваджується ефективна система екскурсійного супроводу і туристичних маршрутів [98].

Що стосується організації та розвитку закладів розміщення, то у 2019 році на відпочинок та оздоровлення туристів приймали 293 заклади відпочинку та оздоровлення, в тому числі 49 дитячих оздоровчих таборів. А також 700 офіційно зареєстрованих міні-готелів та пансіонатів, більше 50 готельних комплексів, 56 садиб сільського зеленого туризму. Загальна місткість ліжкового фонду понад 150 тис. місць [99].

Для підвищення рівня обслуговування в регіоні для готельєрів організовується низка тренінгів із залученням європейських фахівців-експертів 3 розвитку індустрії гостинності. 
Ще одним резервом підвищення привабливості вітчизняних туристичних продуктів $\epsilon$ реконструкція наявної туристичної та соціально-побутової інфраструктури. Санаторно-курортні заклади знаходяться в незадовільному стані і не становлять цінності як лікувальні здравниці. Одним із шляхів вирішення цього питання $є$ зниження кредитних ставок та встановлення відповідних пільг в оподаткуванні.

Розвиток масових комунікацій та інформаційно-комунікаційних технологій має вирішальне значення для формування ефективної туристичної інфраструктури. Значну роль відіграють сучасні електронні засоби інформації: створення інформаційних туристичних порталів в мережі Інтернет, інформаційних туристичних центрів і терміналів на основних туристичних маршрутах.

Так, наприклад, для створення привабливого туристичного іміджу Херсонщини, щорічно проводиться системна рекламно - іміджева кампанія «Херсонщина приваблива цілий рік». Презентацію туристичних та курортнорекреаційних можливостей регіону організовують на заходах національного та міжнародного значення в містах Одесі, Чернігові, Києві, Львові, європейських країнах, на національних та регіональних телеканалах, телевізійних проектах [100].

Кожен рік розповсюджується велика кількість друкованої рекламно інформаційної продукції, календар подій області (фестивалів та івент-заходів), електронний контент «літніх. осінніх, зимових туристичних пропозицій області», висвітлюється безліч відео сюжетів та статей про туристичний потенціал Херсонщини.

Одним з інструментів ефективного функціонування туристичної галузі та розбудова належної інфраструктури, створення належних умов для забезпечення якісного зростання рівня туристичних послуг, є регіональні програми розвитку туризму, які в свою чергу, враховують регіональні особливості та стимулюють інші види економічної діяльності. 
Регіональні програми виконують роль активного засобу регулювання ринкових процесів, інтеграції державних, регіональних інтересів та відносин у туристичній сфері, мобілізації ресурсів для забезпечення цілеспрямованого розвитку територіальної рекреаційної системи в господарському комплексі регіону.

Таким чином, успішне функціонування туристичної галузі та соціальноекономічний розвиток регіону повинні передбачати наступні складові:

1. Формування конкурентоздатного регіонального туристичного ринку (насамперед на основі раціонального використання туристичних ресурсів та сучасної туристичної інфраструктури), що сприятиме забезпеченню задоволення широких потреб вітчизняних та іноземних туристів у туристичних послугах.

2. Розвиток матеріально-технічної бази туристичної інфраструктури, яка набуває великої актуальності і потребує якомога скорішого вирішення. Цей напрям передбачає: розвиток інфраструктури на природно-заповідних територіях; облаштування місць для стоянок $\mathrm{i}$ короткочасних зупинок туристично-екскурсійних автобусів, автотуристів; створення додаткових об’єктів туристичних відвідувань, розширення переліку територій перспективних для запровадження нових туристичних маршрутів; збереження та реконструкція пам’яток архітектури.

3. Формування комплексної регіональної системи рекламноінформаційного забезпечення, що дасть змогу інформувати як внутрішнього так i зовнішнього споживача туристичного продукту (створення інформаційних туристичних центрів; підтримка й поповнення туристичного WEB-порталу; організація регіональних виставок, конференцій, фестивалів, семінарів та інших заходів; замовлення й придбання поліграфічної та відео-рекламнопрезентаційної продукції та сувенірів; популяризація туристичного бренду).

4. Залучення інвестицій, вивчення інвестиційно-привабливих об’єктів і надання консультативної допомоги в реалізації пріоритетних інноваційних проектів у туристичній галузі, участь у щорічних туристичних та економічних 
форумах та виставках; створення та видання туристично-інвестиційного довідника.

5. Одним з основних резервів підвищення привабливості вітчизняних національних та регіональних туристичних продуктів, що впливають на інфраструктуру i обсяг туристичного ринку, є встановлення відповідності параметрів пропонованого туристичного продукту обов'язковим регламентованим стандартам i нормам, що забезпечує його конкурентоспроможність та привабливість. 